\title{
THE EFFECT OF REMOVING THE SOLUBLE HUMUS FROM A SOIL ON ITS PRODUCTIVENESS.
}

\author{
By WILLIAM WEIR, M.A., B.Sc. \\ Carnegie Research Scholar.
}

\section{(Rothamsted Experimental Station.)}

THE decay of plant and animal residues in soils produces brown organic compounds commonly designated as humus. Some of it is soluble in dilute alkaline solutions, and agricultural chemists and investigators have often assumed that this part plays an important function in the nutrition of plants by reason of its solubility. As a result numerous methods have been devised for determining this readily soluble material, and its amount has been regarded as a measure of the fertility of the soil. Since however the amount of nitrogen in the soluble humus material is commonly 40 per cent. to 50 per cent. of the total nitrogen, the results for ordinary soils gave no better indication of potential fertility than did the total nitrogen determination itself ${ }^{1}$.

Few experiments seem to have been made to ascertain directly if the soluble humus really does play any considerable part in plant nutrition. The only one that has been found is recorded by Grandeau ${ }^{2}$ in 1872. A kilogramme of Russian Black Earth was divided into two parts; one was treated with dilute hydrochloric acid and ammonia solution to remove soluble humus, or, as he termed it, matière noire; the other was left untreated.

The two lots of soil were put into flower pots and watered to saturation point with distilled water, the untreated soil taking 7 per cent.

1 "Results of Investigations on the Rothamsted Soils," 1902, by Bernard Dyer. N. H. J. Miller's “Determinations," p. 179.

2 "Recherches sur lo rôle des matières organiques du sol dans les phénomènes de la nutrition des végétaux," par M. L. Grandeau. Publication de la Station agronomique de $I E$ st. 1872. 
more water than the other. Beans were planted in both: they developed normally on the untreated soil but failed entirely on the extracted soil.

During the past two seasons this experiment has been repeated on a larger scale, with results sufficiently interesting to justify their being placed on record. The removal of the soluble humus was effected by. washing the soil with dilute hydrochloric acid to remove bases, and then repeatedly extracting with dilute soda. Some 40 per cent. of the nitrogen in the soils was thereby removed.

Vegetation experiments were then conducted with large quantities of untreated and extracted soils, and approximately equal total yields both of dry matter and of nitrogen were obtained over four successive crops. Thus it appears that the removal of the soluble humus had no effect in diminishing the productiveness of the soil in spite of the fact that the soil used was known to respond to nitrogenous fertilisers.

Laboratory experiments were then started to ascertain the effect of removing soluble humus on the rates of production of nitrate and ammonia in the soils. Here the indications were that the removal of the soluble humus increased the amount of ammonia but diminished that of nitrates in the soil, and the sum of ammonia and nitrate was usually less than in the untreated soil. The numbers of bacteria however were considerably increased. No marked difference was produced where 0.5 per cent. untreated soil was added to replace the bacterial flora that might have been destroyed by the acid and alkali treatment. These results are not necessarily inconsistent with the vegetation experiments. It has been shown in these laboratories that the accumulation of ammonia and nitrate in an uncropped soil will only proceed to a certain stage when it stops ${ }^{1}$. In vegetation experiments on the other hand the nitrate is perpetually being removed by the growing plant. There is thus a considerable difference in conditions.

Method of Extraction. 250 grams of air-dried soil, which has passed through a $3 \mathrm{~mm}$. sieve, are shaken up with 2500 c.c. N/5 HCl. After standing in contact with the acid for one hour, the soil is thrown on to a filtering funnel and washed free of acid; 500 grams of soil treated in this manner are shaken with 2000 c.c. 2 per cent. $\mathrm{NaOH}$ and allowed to settle overnight. The dark-coloured humus extract is siphoned off. This process is repeated five times in all, and at the fifth extraction the liquid is of a lightish brown tint. The soil is then shaken with water, allowed to settle, the supernatant liquid is removed, and finally the

1 "The Effect of Partial Sterilisation of Soil on the Production of Plant Food," by E. J. Russell, ard H. B. Hutchinson. Journal of Agricultural Science, v. p. 193.

Journ. of Agrio. Sci. vIr 
whole is made slightly acid with $\mathrm{HCl}$ to promote flocculation and allow of easy filtration and washing. The acid is then removed, the soil dried and passed through a $3 \mathrm{~mm}$. sieve.

The soils used were: (1) Allotment soil, a medium garden soil; (2) Harpenden Field Soil (Arable), a typical loam. The treatment was found to reduce the nitrogen very considerably.

\section{TABLE I.}

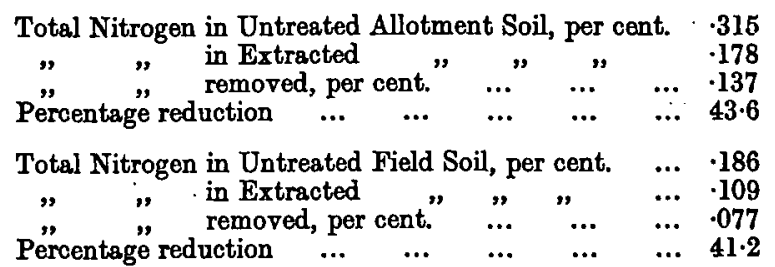

Vegetation experiments were made with the four soils (Untreated Allotment, Extracted Allotment, Untreated Field Soil, and Extracted Field Soil respectively).

Each pot had a capacity of 10 kilos.; 5 kilos. sharp sand were put at the bottom, and above this 5 kilos. of the soil under investigation, mixed with 15 per cent. of sharp sand. Each set consisted of 5 pots: thus there were 20 pots in all. Chalk was added to replace carbonates removed by the acid treatment and 1 gram $\mathrm{KH}_{2} \mathrm{PO}_{4}$ in solution was added to each pot. Thus the soils were as follows:

TABLE II.

\begin{tabular}{|c|c|c|c|c|c|}
\hline & & $\begin{array}{l}\text { Untreated } \\
\text { Allotment }\end{array}$ & $\begin{array}{l}\text { Extracted } \\
\text { Allotment }\end{array}$ & $\begin{array}{l}\text { Untreated } \\
\text { Harpenden }\end{array}$ & $\begin{array}{c}\text { Extracted } \\
\text { Harpenden }\end{array}$ \\
\hline $\begin{array}{ll}\text { Fine Earth } \\
\text { Sand } \quad \ldots \\
\text { Chalk } & \ldots \\
\mathrm{KH}_{2} \mathrm{PO}_{2} & \ldots\end{array}$ & $\begin{array}{l}\cdots \\
\cdots \\
\cdots \\
\cdots\end{array}$ & $\begin{array}{c}5000 \text { grams } \\
750 \text { _" } \\
1 \text { gram }\end{array}$ & $\begin{array}{c}5000 \text { grams } \\
750 " \\
21 \text { " } \\
1 \text { gram }\end{array}$ & $\begin{array}{c}5000 \text { grams } \\
750 \text { _" } \\
1 \text { gram }\end{array}$ & $\begin{array}{c}5000 \mathrm{grams} \\
750 \mathrm{~g} \\
47 \cdot 5 " \\
1 \mathrm{gram}\end{array}$ \\
\hline
\end{tabular}

Wheat was sown on March 14th, 1914, and the pots were kept in the . glass-house till April 7th when the number of plants was reduced to five per pot and all the pots were removed to the open. The plants in all cases made slow growth; those in the untreated soils tillered better, but later in the growing period were caught up, and passed by those in the treated soils. Subsequent growth was quite satisfactory, and in August, when the crops were cut, the weights were: 
TABLE III. Weights of first crop, Wheat.

\begin{tabular}{|c|c|c|c|c|}
\hline Soil & & $\begin{array}{l}\text { Weight of } \\
\text { Wheat dried } \\
\text { at } 100^{\circ} \mathrm{C} \text {. }\end{array}$ & $\begin{array}{l}\text { Percentage } \\
\text { of Nitrogen } \\
\text { in crop }\end{array}$ & $\begin{array}{l}\text { Weight of } \\
\text { Nitrogen } \\
\text { in crop }\end{array}$ \\
\hline $\begin{array}{l}\text { Allotment Soil ... } \ldots \\
\text { Allotment Soil Extracted } \\
\text { Harpenden Field Soil ... } \\
\text { Harpenden Field Soil Extracted }\end{array}$ & $\begin{array}{l}\cdots \\
\cdots \\
\cdots\end{array}$ & $\begin{array}{c}\text { grams } \\
67 \cdot 8 \\
72 \cdot 3 \\
45 \cdot 3 \\
67 \cdot 2\end{array}$ & $\begin{array}{r}.95 \\
1.01 \\
.82 \\
1.06\end{array}$ & $\begin{array}{l}\text { grams } \\
.64 \\
.73 \\
.37 \\
.71\end{array}$ \\
\hline
\end{tabular}

After the wheat was cut the soils were thrown out of the pots, mixed up afresh and replaced as before. Mustard was then sown (still in August), during rather dry weather, and was grown in the open. Only on Harpenden Field Soil was any appreciable yield obtained: on the extracted soil the plants scarcely grew beyond the seed-leaf stage. On both allotment soils the crops were poor. The mustard was pulled on October 8th and dried and weighed as before.

TABLE IV. Weights of second crop, Mustard.

\begin{tabular}{|c|c|c|c|c|}
\hline Soil & & $\begin{array}{l}\text { Weight of } \\
\text { Mustard dried } \\
\text { at } 100^{\circ} \mathrm{C} \text {. }\end{array}$ & $\begin{array}{c}\text { Percentage } \\
\text { of Nitrogen } \\
\text { in crop }\end{array}$ & $\begin{array}{l}\text { Weight of } \\
\text { Nitrogen } \\
\text { in crop }\end{array}$ \\
\hline $\begin{array}{l}\text { Allotment Soil } \ldots \\
\text { Allotment Soil Extracted } \\
\text { Harpenden Field Soil ... } \\
\text { Harpenden Field Soil Extracted }\end{array}$ & $\begin{array}{l}\cdots \\
\cdots \\
\cdots\end{array}$ & $\begin{array}{r}\operatorname{grams} \\
2 \cdot 7 \\
3 \cdot 9 \\
13 \cdot 1 \\
\cdot 9\end{array}$ & $\begin{array}{r}2 \cdot 34 \\
+2 \cdot 51 \\
1 \cdot 93 \\
3 \cdot 44\end{array}$ & $\begin{array}{c}\text { grams } \\
-.06 \\
.08 \\
.25 \\
.03\end{array}$ \\
\hline
\end{tabular}

TABLE V. Weights of third crop, Rye:

\begin{tabular}{|c|c|c|c|c|}
\hline Soil & & $\begin{array}{l}\text { Weight of } \\
\text { Rye dried } \\
\text { at } 100^{\circ} \mathrm{C} \text {. }\end{array}$ & $\begin{array}{l}\text { Percentage } \\
\text { of Nitrogen } \\
\text { in crop }\end{array}$ & $\begin{array}{l}\text { Weight of } \\
\text { Nitrogen } \\
\text { in crop }\end{array}$ \\
\hline $\begin{array}{ll}\text { Allotment Soil } \ldots & \ldots \\
\text { Allotment Soil Extracted } & \ldots \\
\text { Harpenden Field Soil } \ldots & \ldots \\
\text { Harpenden Field Soil Extracted }\end{array}$ & $\begin{array}{l}\cdots \\
\cdots \\
\cdots\end{array}$ & $\begin{array}{c}\text { grams } \\
3 \cdot 1 \\
3.7 \\
5 \cdot 4 \\
6.6\end{array}$ & $\begin{array}{l}3 \cdot 94 \\
3 \cdot 68 \\
3 \cdot 66 \\
4 \cdot 17\end{array}$ & $\begin{array}{c}\text { grams } \\
.12 \\
.14 \\
.20 \\
.28\end{array}$ \\
\hline
\end{tabular}

The soils were then cultivated but not otherwise disturbed. On October 13th all the pots were sown with rye, which grew in the glasshouse till 18th February, 1915, when the plants, 10 to each pot, were 
pulled, as it seemed unnecessary to allow them to ripen. The crops were dried, weighed, and the nitrogen determined as before. The soil in all the pots was thrown out and thoroughly dried before replacing in the pots and sowing with a fourth crop-mustard.

Mustard was sown in all the pots in April, 1915, and was left till the end of May when it was pulled, dried: and weighed. There was a fair crop on all the soils except on the Extracted Harpenden Field Soil, where it failed entirely. The plants were cut when just flowering.

TABLE VI. Weights of fourth crop, Mustard.

\begin{tabular}{|c|c|c|c|c|}
\hline Soil & & $\begin{array}{l}\text { Weight of } \\
\text { Mustard dried } \\
\text { at } 100^{\circ} \mathrm{C} \text {. }\end{array}$ & $\begin{array}{l}\text { Percentage } \\
\text { of Nitrogen } \\
\text { in crop }\end{array}$ & $\begin{array}{l}\text { Weight of } \\
\text { Nitrogen } \\
\text { in crop }\end{array}$ \\
\hline $\begin{array}{l}\text { Allotment Soil ... } \ldots \\
\text { Allotment Soil Extracted } \\
\text { Harpenden Field Soil ... } \\
\text { Harpenden Field Soil Extracted }\end{array}$ & $\begin{array}{l}\cdots \\
\cdots \\
\cdots\end{array}$ & $\begin{array}{c}\text { grams } \\
11 \cdot 3 \\
10.8 \\
15 \cdot 4 \\
1.3\end{array}$ & $\begin{array}{l}2 \cdot 12 \\
2 \cdot 19 \\
1 \cdot 97 \\
3 \cdot 53\end{array}$ & $\begin{array}{l}\text { grams } \\
.24 \\
.24 \\
.30 \\
.05\end{array}$ \\
\hline
\end{tabular}

Table VII gives a summary of the crop and nitrogen data for the different soils.

TABLE VII. Summary of weights of all four crops.

\begin{tabular}{|c|c|c|c|c|c|c|c|c|c|c|}
\hline Soil & 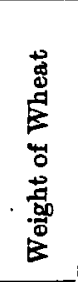 & 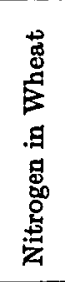 & 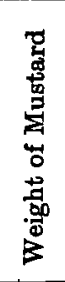 & 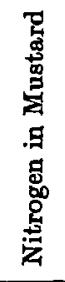 & 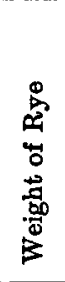 & 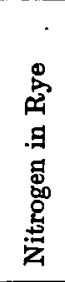 & 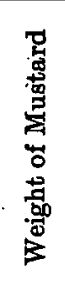 & 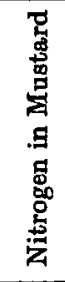 & 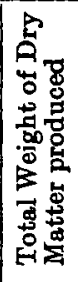 & 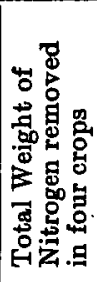 \\
\hline Allotment Soil & $\begin{array}{l}\text { gms. } \\
67.8\end{array}$ & $\%$ & $\begin{array}{r}\text { gms. } \\
2 \cdot 7\end{array}$ & $2 \%$ & $\underset{3 \cdot 1}{\text { gms. }}$ & $\begin{array}{l}\% \\
3.94\end{array}$ & $\underset{11.3}{\operatorname{gms} .}$ & $\begin{array}{r}\% \\
2 \cdot 12\end{array}$ & $\begin{array}{l}\operatorname{gms} . \\
84 \cdot 9\end{array}$ & $\begin{array}{r}\% \\
1.07\end{array}$ \\
\hline $\begin{array}{l}\text { Allotment Soil } \\
\text { Extracted }\end{array}$ & $72 \cdot 3$ & 1.01 & $3 \cdot 9$ & $2 \cdot 61$ & $3 \cdot 7$ & $3 \cdot 68$ & 10.8 & $2 \cdot 19$ & $90 \cdot 7$ & $1 \cdot 19$ \\
\hline $\begin{array}{l}\text { Harpenden Field } \\
\text { Soil }\end{array}$ & $45 \cdot 3$ & .82 & $13 \cdot 1$ & 1.93 & $5 \cdot 4$ & $3 \cdot 66$ & $15 \cdot 4$ & $1: 97$ & $79 \cdot 2$ & $1 \cdot 13$ \\
\hline $\begin{array}{l}\text { Harpenden Field } \\
\text { Soil Extracted }\end{array}$ & $67 \cdot 2$ & 1.06 & .9 & 3.44 & $6 \cdot 6$ & $4 \cdot 17$ & 1.3 & $3 \cdot 53$ & $76 \cdot 0$ & 1.07 \\
\hline
\end{tabular}

Thus it will be seen that in five cases out of eight the plants obtained more nitrogen from the extracted than from the untreated soils, in one 
case the amount was the same and in two cases the amount was less but on both these occasions the crop (mustard) failed on one soil.

TABLE VIII. Nitrogen in soils and crops.

\begin{tabular}{|c|c|c|c|c|}
\hline Soil & & $\begin{array}{l}\text { Percentage } \\
\text { of Nitrogen } \\
\text { in Soil }\end{array}$ & $\begin{array}{l}\text { Total Weight } \\
\text { of Nitrogen } \\
\text { per pot }\end{array}$ & $\begin{array}{l}\text { Total Nitrogen } \\
\text { removed in } \\
\text { four crops }\end{array}$ \\
\hline $\begin{array}{l}\text { Allotment Soil ... } \ldots . \\
\text { Allotment Soil Extracted } \\
\text { Harpenden Field Soil } \ldots . \\
\text { Harpenden Field Soil Extracted }\end{array}$ & $\begin{array}{l}\ldots \\
\cdots \\
\cdots\end{array}$ & $\begin{array}{l}.315 \\
.178 \\
.186 \\
.109\end{array}$ & $\begin{array}{r}\text { grame } \\
15 \cdot 74 \\
8 \cdot 88 \\
9 \cdot 28 \\
5 \cdot 46\end{array}$ & $\begin{array}{l}\text { grams } \\
1.07 \\
1 \cdot 19 \\
1.13 \\
1.07\end{array}$ \\
\hline
\end{tabular}

During the winter of 1914-1915 additional quantities of the same two soils were extracted and used in vegetation experiments in precisely the same way as in the previous sets. In this instance the acid and alkali treatment removed a somewhat smaller amount of the soluble humus matter from both soils.

\section{TABLE IX.}

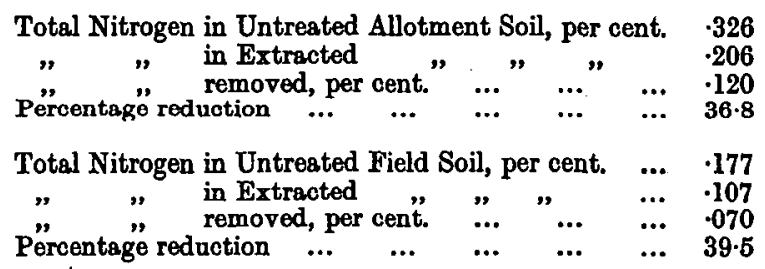

In the case of the Allotment Soil, wheat was sown in the pots on November 12th, 1914. The plants in the untreated soil grew and tillered better thin the others but in both sets the crops were good. They were cut when nearly in full ear on 23rd June, 1915.

Wheat was not sown in the Harpenden soils till 25th March, 1915, so that the growing period was much the same as for the wheat crops of the previous season. It was cut on 23rd June, 1915, when the ears were beginning to come out.

The yields were comparatively poor but during the whole time the plants in the extracted soil were greener in the leaves and did better than those in the untreated. The following figures were obtained for the four soils on cutting and drying: 
TABLE X.

\begin{tabular}{|c|c|c|c|c|}
\hline$\ldots \ldots \ldots{ }^{\text {Soil }} \quad \ldots$ & & $\begin{array}{l}\text { Weight of } \\
\text { Wheat dried } \\
\text { at } 100^{\circ} \mathrm{C} \text {. }\end{array}$ & $\begin{array}{l}\text { Percentage } \\
\text { cf Nitrogen } \\
\text { in crop }\end{array}$ & $\begin{array}{l}\text { Weight of } \\
\text { Nitrogen } \\
\text { in crop }\end{array}$ \\
\hline $\begin{array}{l}\text { Allotment Soil . . } \\
\text { Allotment Soil Extracted } \\
\text { Harpenden Field Soil .... } \\
\text { Harpenden Field Soil Extracted }\end{array}$ & $\begin{array}{l}\ldots \\
\cdots \\
\cdots \\
\cdots\end{array}$ & $\begin{array}{l}\text { grams } \\
148 \cdot 9 \\
127 \cdot 7 \\
47 \cdot 8 \\
5.7 \cdot 7\end{array}$ & $\begin{array}{r}.82 \\
.82 \\
1 \cdot 18 \\
1 \cdot 25\end{array}$ & $\begin{array}{l}\text { grams } \\
1 \cdot 22 \\
1 \cdot 05 \\
.56 \\
.72\end{array}$ \\
\hline
\end{tabular}

Experiments on the rate of nitrate production in the soil. These were made with Untreated and Extracted Allotment Soils respectively, and they involved periodical determinations of nitrate, ammonia, and numbers of bacteria. Chalk was added to replace the carbonates removed during extraction, and a third set was put up consisting of extracted soil plus carbonate, seeded with 0.5 per cent. of untreated soil to replace the bacterial flora that might have been destroyed by the acid and alkali treatment. Estimations were made at the start, after one week, after three weeks, and after a considerable period. The soils were stored in bottles, and the moisture content adjusted to approximately 16 per cent., this being known as favourable for bacterial action. Table XI shows the changes that occur.

It will be seen that the formation of nitrate is less marked in the treated soils, and that ammonia tends to occur in quantity and to persist, whilst the untreated soil contains only the normal three or four parts per million. Further, while the numbers of bacteria in the untreated soil are normal throughout--about 20 millions per gram downwards-the numbers in the extracted soils are initially very low, then become abnormally high and remain above the usual level; there is however no corresponding increase in the production of ammonia and nitrate. This is very similar to the result obtained by W. Buddin ${ }^{1}$ on treating soils with non-volatile antiseptics. Sowing the extracted soil with bacteria from untreated soil causes no marked difference in the results.

1. Journal of Agricultural Science, 1914, vI. pp. 417-451. 


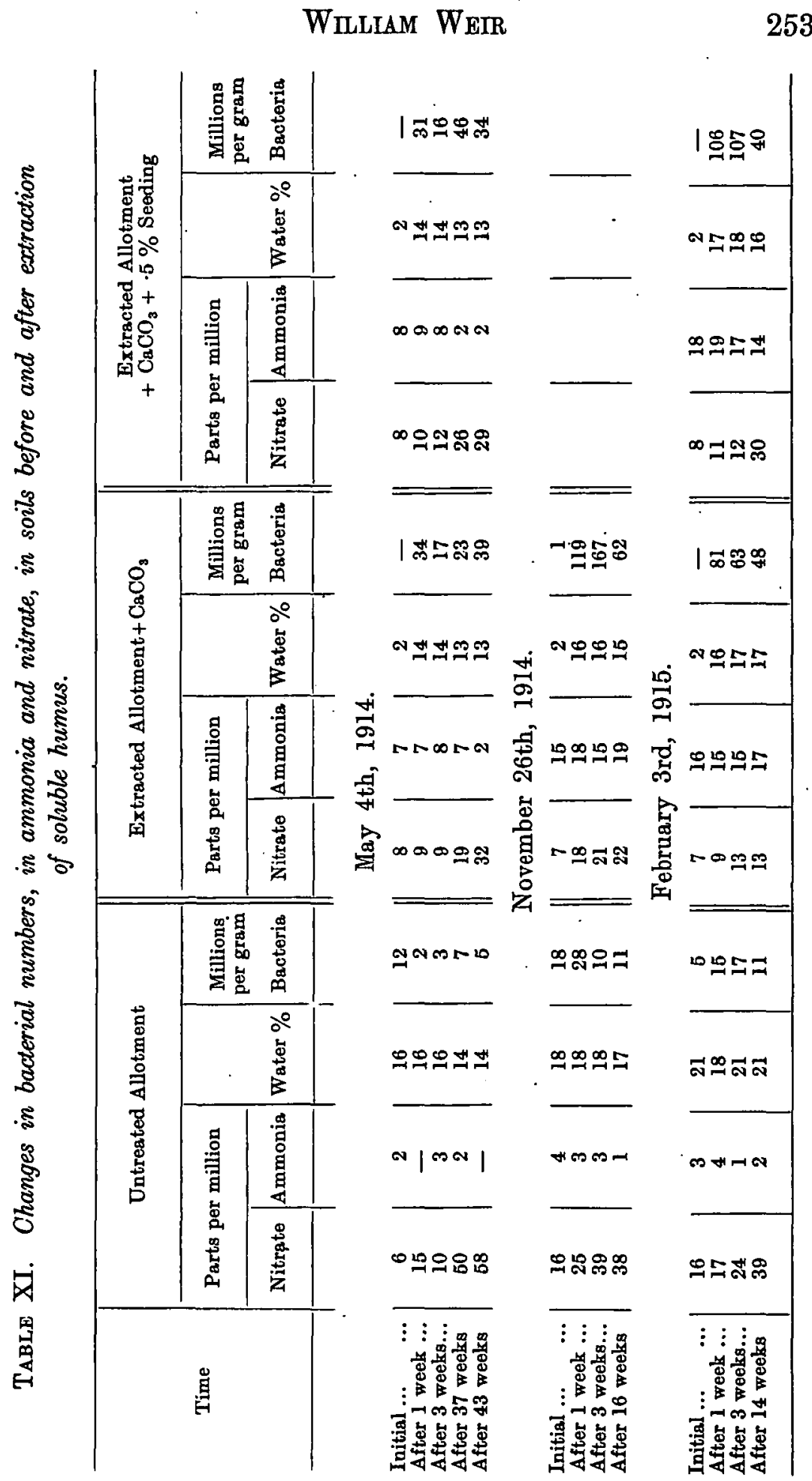

(Received July 26th, 1915.) 